\title{
VARGA ATTILA
}

\section{Az emberi méltóság és a személyiségi jogok összefüggései (alkotmányi és polgári jogi szabályozásuk kritikai értelmezése)}

\section{The relationship between human dignity and personality rights (critical interpretation of their constitutional and civil law regulation)}

Abstract: The issue indicated in the title of the study is essentially a complex of legal problems, which raise several questions about the concepts used, such as: What is human dignity? What rights can be derived from it? Can we talk about the right to human dignity? What is personhood? What are the personality rights? How is human dignity related to the personality rights? The study examines the problem from the perspective of Romanian legislation and Constitutional Court practice.

Keywords: human dignity, personality rights, Romanian Constitution, Romanian Civil Code, Constitutional Court

Összefoglaló: A tanulmány címében jelzett kérdéskör lényegében egy jogi problémahalmaz, mely már a használt fogalmakkal kapcsolatosan is több kérdést vet fel, úgymint: Mi az emberi méltóság? Milyen jogok származtathatók ebből? Beszélhetünk-e az emberi méltósághoz való jogról? Mi a személyiség? Melyek a személyiségi jogok? Milyen összefüggésben van az emberi méltóság a személyiségi jogokkal? A tanulmány a román szabályozás és alkotmánybírósági gyakorlat szemszögéből vizsgálja a problémát.

Kulcsszavak: emberi méltóság, személyiségi jogok, román Alkotmány, román Polgári törvénykönyv, Alkotmánybíróság

\section{Bevezetö}

Az alkotmányjog és a polgári jog eltérő módon értékeli és értelmezi az emberi méltóságot és a személyiségi jogokat, valamint a közöttük lévő összefüggéseket.

Az 1990 utáni alkotmányos rendszerben, illetve a 2011-es új Polgári törvénykönyv szabályozásának rendjében e felfogás radikálisan megváltozik a korábbi szabályokhoz és a szabályozási koncepciókhoz képest. Természetesen nem is lehet másképpen, hiszen egyrészt megváltozott a politikai rendszer, másrészt az alapvető emberi jogok 
vonatkozásában, a nemzetközi jogi szabályozásban, illetve egyes államok alkotmánybírósági gyakorlatában jelentősen felértékelődött az emberi méltóság és a személyiségi jogok biztosításának követelménye. Az emberi méltóság mint alkotmányos érték egyben normatív tartalommal is rendelkezik, másrészt a személyiségi jogok köre kiszélesedett, és immáron nem elegendő ezek jogszabályi, akár alkotmányi kinyilatkoztatása, hanem hatékony garanciális szabályokkal is el kell látni.

A tanulmány címében jelzett kérdéskör lényegében egy jogi problémahalmaz, mely már a használt fogalmakkal kapcsolatosan is több kérdést vet fel, úgymint: Mi az emberi méltóság? Milyen jogok származtathatók ebből? Beszélhetünk-e az emberi méltósághoz való jogról? Mi a személyiség? Melyek a személyiségi jogok? Ezek hogyan viszonyulnak a személyhez füződő jogokhoz? Milyen összefüggésben van az emberi méltóság a személyiségi jogokkal? E kérdéseknek normatív, szabályozási szempontból természetesen egy alkotmányjogi és egy polgári jogi kerete, valamint egy viszonylag új keletű, jogdogmatikai szempontból nem kellőképpen kimunkált jogtudományi értelmezése, kommentárja és egy szintén nem túl bőséges, alkotmánybírósági gyakorlata van.

A személyhez fủződő jogok hosszú ideig, így a régi román Polgári törvénykönyv (mely 1864-2011 között volt hatályban) szabályozása szerint is alapvetően a vagyoni jellegü viszonyokkal kapcsolódott össze, és csak a későbbiekben jelentek meg az azonosságra szolgáló elemek, úgymint a névhez, a lakhelyhez, tartózkodási helyhez és családi állapothoz köthető nem vagyoni jellegủ jogok. A második világháborút követően Európa nyugati felében a már létező személyhez füződő jogok mellett megjelennek a személyiségi jogok - lényegüket tekintve - mint nem vagyoni jogok, valamint a személyiségi jogvédelem. A személyiségi jogok és az ezzel kapcsolatos jogvédelem pedig idővel egyre bővült részint az általánosodás irányába mint általános személyiségi jog, részint új konkrét személyiségi jogok megjelenése és ezek védelmének irányába.

A személy fogalmának jogi felértékelődése, tartalmi bővülése, mely a személyiség összetettebb fogalmához vezetett el, egyben a személyiségi jogok jelentős kiterjedését is eredményezte, melynek megértése, értelmezése elválaszthatatlan az alkotmányban rögzített alapjogoktól, szabadságjogoktól.

Jelentős késéssel ez a folyamat a román jogrendszerben is lezajlott, legalábbis ami a jogi szabályozást illeti, ugyanakkor a jogalkalmazás, a bírói és különösen az alkotmánybírósági jogértelmezés, valamint a magyarázó jogtudomány adós maradt ezen újszerű fogalmak és jelenségek elméleti, doktrinális megalapozásával. Ha nem is mentségül, de elfogadható magyarázatul szolgál, hogy a román jogrendszer, ahogyan a többi kelet-közép-európai volt szocialista ország is, jelentős hátránnyal indult, hiszen a korábbi politikai rendszer szocialista jogtudománya nem ismerte (el) a személyiségi jogok fogalmát, vagy ha igen, akkor ezt „arra a kérdésre szükitette le, hogy hogyan illeszthetők bele ezek a nem vagyoni jogok a vagyoni viszonyokat szabályozó polgári jogba". ${ }^{1}$ Ebből pedig csak addig jutott, hogy megalapozta a személyhez fủződő jogok függetlenségét a vagyoni jogoktól.

2021-ben, immáron kellő időperspektívából szemlélve a még mindig újnak nevezett, tízéves román Polgári törvénykönyvet, megállapítható, hogy a személyiségi jogokról szóló rész, pontosabban a személyekről szóló I. könyv II. fejezete, mely „Az emberi lény és vele

1 Kecskés László: Polgárijog. A személyek joga, Dialóg Campus Kiadó, Budapest-Pécs, 2007, 415. 
Az emberi méltóság és a személyiségi jogok összefüggései...

születettjogainak tiszteletben tartása" nem éppen szokványos megnevezése alatt szerepel, kivételes jelentőségű a személy, a személyiség új koncepció szerinti alapokra helyezett polgári jogi szabályozásában. Ugyanakkor ez az a fejezet, amely szervesen kötődik a román alkotmány egyrészt általános rendelkezéseihez, mely az alkotmányos értékrendet határozza meg, másrészt az alapvető emberi jogok és szabadságjog katalógusához. A személy fogalmának átértékelődése, a személyiség jogi koncepciója és a személyiségi jogok védelme azonban az alkotmányos rendelkezésekkel az ezekben megjelenő értékek, elvek és szabályok által kezdődött el és vált lehetségessé.

\section{Alkotmányi szabályozások. Emberi méltóság}

\subsection{Az emberi méltóság mint legföbb érték és/vagy mint alapjog}

Miközben joggal azt gondolnánk, hogy az emberi méltóság univerzális tartalommal rendelkezik, hiszen minden ember méltósága csak egyenlő vagy akár egyforma lehet, addig az egyes országok jogi méltóságfogalma igencsak eltérő. Nem véletlen, hiszen az emberi méltóság fogalmának értelmezése, jelentésrétegeinek alakulása lényegében egyidős a két és fél ezer éves filozófiatörténettel. Kétségtelen, hogy a fogalomnak konkrét jogi tartalmat tulajdonítani, azaz konkrét alanyi jogként kezelni meglehetősen nehéz. A fogalom tartalmának bizonytalansága miatt is eltérő felfogásokon alapuló szabályozások jelentek meg. Az eltérő felfogások egyik sarkalatos kérdése, hogy milyen, ha lehet így fogalmazni, eredetviszonyt határoznak meg az emberi méltóság és a személyiségi jogok között. Az egyik felfogásban az emberi méltóság a személyiség szerves része, a méltósághoz való jog pedig egy a személyiségi jogok közül. A másik felfogásban az emberi méltósághoz való jog olyan „anyajog”, amelyből a legtöbb alapjog vagy éppen alanyi jog ered, az emberi méltóság sajátos normatív tartalma alapozza meg a legtöbb alapjogot, beleértve a személyiségi jogokat is, mi több, megalapozza az alkotmány értékrendszerét, ezáltal pedig egységét is. E két eltérő felfogásból adódik az a különbség is, mely szerint az emberi méltóság kizárólag mint alapérték, legfőbb érték jelenik meg az alkotmányos jogrendszerben, anélkül, hogy konkrét alanyi jogi tartalma lenne, avagy éppen ellenkezőleg, az emberi méltósághoz való jog egy kiemelt jelentőségű, (közvetett) normatív tartalommal rendelkező alapjog.

A román jogi, alkotmányjogi felfogás az előbbihez áll közelebb, mivel sokkal inkább valamilyen metafizikai (metajogi) tartalmat, és kevésbé konkrét, jogi jelentést tulajdonít az emberi méltóságnak. Ezen azonban az Alkotmánybíróság értelmező gyakorlata jelentősen változtatott. A másik felfogást alapvetően a második világháborút követő német alkotmányjogi gondolkodás és alkotmánybírósági gyakorlat alapozta meg, és fejlesztette egy rendkívül egységes, koherens koncepció szintjére. Először néhány, a második felfogásra, és különösen a német méltóság koncepcióra vonatkozó jellemzőt említek, Zakariás Kingának a témában talán a legátfogóbb elemzést végző, monografikus jellegü doktori értekezéséből idézve. 
A német szövetségi Alkotmány 1. cikke kimondja, hogy „Az emberi méltóság sérthetetlen. Ennek tisztelete és védelme minden állami hatalom (hatóság) kötelessége". Azáltal, hogy ez kötelezettséget ró az állam minden közhatósága számára az emberi méltóság tisztelete és védelme vonatkozásában, alapjogi jelleget biztosít számára, mégpedig olyan módon, hogy kiemeli a többi alapjog közül, azáltal, hogy megalapozza az alapjogok és különösen a személyiségi jogok által alkotott objektív alkotmányos értékrendszert. ${ }^{2}$ Ahogyan még egy 1952-es német szövetségi alkotmánybírósági határozatban megfogalmazott indoklásból leszűrhető, a taláros testület összekapcsolta az emberi méltóságot és az abból következő szabadság és egyenlőség értékét az alkotmányos renddel. Az alapjogi rendszer tehát önmagában is egy alkotmányos értékrendet képvisel, amit éppen az emberi méltóságra történő hivatkozással alapozott meg a német alkotmány. Ennek jelentősége pedig kettős: „egyrészt az ember önértékéből következő szabadsága és egyenlősége szintén értékek, amelyre tekintettel az államrend értékekhez kötött, másrészt ezek az értékek, amelynek a középpontjában a személyiség és annak méltósága áll, maguk is egy értékrendszert alkotnak. Az emberi méltóság úgy alapozza meg az alkotmány egységét és az általa védett értékrendszert, hogy [...] minden alapjog lényeges tartalmának részét képezi.”3

Az alkotmány értékrendjével kapcsolatban, melynek mondhatni központi magja az alapjogi fejezet és az általa képviselt értékrendszer, a Szövetségi Alkotmánybíróság elhíresült Lüth-ítéletében megfogalmazta, hogy a német Alkotmány (Grundgesetz), „amely nem akar értéksemleges rend lenni [...], az alapjogi fejezetében felállitott egy objektiv értékrendet, és pontosan ezáltal jut kifejezésre az alapjogok érvényesülésének a megerösödése. [...] Ennek az értékrendnek, amelynek középpontjában a társadalomban szabadon fejlődő személyiség és annak méltósága áll, alkotmányos alapelvként érvényesülnie kell minden jogterületen: innen kap irányelveket és impulzusokat a törvényalkotás, közigazgatás és a bírói hatalom."

Azt figyelhetjük meg, ami akár jogi paradoxonnak is tủnhet, hogy miközben a német alkotmány az emberi méltóságot nem jogként fogalmazza meg szövegszerűen, az ezzel kapcsolatos állami kötelezettségek előírása vitathatatlanná teszik az emberi méltóság normatív, mi több, alapjogi jellegét. Ezt csak megerősíti a német alkotmány örökkévalósági klauzulája [79. cikk (3) bekezdése], mely korlátot szab az alkotmányozó hatalomnak is az emberi méltóság érinthetetlensége, sérthetetlensége és korlátozhatatlansága vonatkozásában.

A korábbi magyar Alkotmány, de a jelenlegi Alaptörvény is jogként, alapjogként fogalmazta meg az emberi méltóságot, bár ez utóbbiban megjelenik nem jogként is, egyszerủen emberi méltóság kifejezésként. Mind a német, mind a magyar alkotmánybírósági gyakorlat kimondja, hogy az emberi méltóságból eredően minden embernek igénye van arra, hogy az összes állami eljárásban alanyként és ne tárgyként kezeljék, és

2 ZAKARIÁs Kinga: Az emberi méltósághoz való alapjog, Összehasonlitó jogi elemzés a német és magyar alkotmánybirósági gyakorlat tükrében, Pázmány Péter Katolikus Egyetem, Jog- és Államtudományi Kar, Doktori Iskola, Budapest, 2017, 54. A szerző idézi az Alkotmánybíróságnak egy német neonáci párt betiltásával kapcsolatos indoklását BVerfGE 2, 1 (12).

3 Uo., 55.

4 BVerfGE 7, 198 (205). Idézi ZaKariás Kinga: i. m., 54. A Lüth-ítéletről lásd még SóLYom Péter: Alapjogokra hangolva. A Lüth-ítélet jogtörténeti nézőpontból, Fundamentum, 2007/3, 91-95. 
Az emberi méltóság és a személyiségi jogok összefüggései...

minden olyan állami cselekvés tilos, amely az ember lealacsonyitását, megbélyegzését, üldözését, elüzését célozza.

Mindezekhez képest a román Alkotmány az emberi méltóságot (egyébként nem helytelenül) mint legfőbb alkotmányos értéket jelöli meg, többek között a személyiség szabad fejlődésével és az igazságossággal együtt. Ez kétségtelenül meghatározó jelleggel rendelkezik az alkotmányos és benne az alapjogi értékrendre, megalapozza a legtöbb alapjogot és különösen a személyiségi jogokat. Ugyanakkor az alkotmány tételes alapjogi jelleggel nem ruházza fel, és az Alkotmánybíróság gyakorlata sem biztosít kellő mélységủ és konzisztens tartalmú értelmezést, érvelést az emberi méltóság normatív, alapjogi jellegének kellő alátámasztására. Ez természetesen nem jelenti az emberi méltóságfogalom jelentőségének kétségbevonását, de kevéssé ismerte fel mind a jogtudomány, mind az alkotmányos igazságszolgáltatás az emberi méltóságban rejlő koncepcionális erőt és lehetőséget az egyes alapjogok megalapozására, vagy akár jogi, alkotmányossági viták megoldására.

A román alkotmány (a német alaptörvénytől eltérően) az állammal kezdődik, és az egész első cím az általános elvekről jelentős mértékben az állam önmeghatározásáról, jellemzőiről, a főbb hatalomgyakorlási elvekről szól, és majd a második cím tartalmazza az alapjogi elveket és az alapjogi katalógust, majd a további hat (de különösen a legterjedelmesebb harmadik) cím az államszervezettel foglalkozik. Nem hinném, hogy ez önmagában helytelen lenne, hiszen több európai alkotmánynak hasonló a szerkezete, legfeljebb néhány koncepcionális alapvetést, szemléletbeli hozzáállást lehetne kritika alá vonni.

\subsection{Az emberi méltóság hagyományos és sajátos funkciói}

Korántsem jelképes az, hogy a német alkotmány szövege, szabályozása az emberrel, az emberi méltóság sérthetetlenségének kijelentésével kezdődik. Tehát nem az állammal, még csak nem is az állampolgárral, hanem az emberrel.

Az alkotmányi normatartalmat megerősítve, kibontva, illetve megalapozva, a Szövetségi Alkotmánybíróság több évtizedes, több mint fél évszázados gyakorlata valóságos doktrínáját dolgozta ki az emberi méltóság koncepciójának és az ebből fakadó gyakorlati jogkövetkezményeknek. El egészen addig a megállapításig, hogy végső soron maga az állam léte is az ember méltóságán, az egyén önálló cselekvésén alapul, ugyanis az állam van az emberek akaratából, és nem az emberek az állam akaratából. A német alkotmány preambuluma is megfogalmazza az ember elsőbbségének gondolatát, ugyanis az alkotmányozó hatalom az „Isten és az emberek elötti felelösségének tudatában, a nép alkotmányozó ereje által alkotta meg az Alaptörvényt”. Az Alaptörvény, az Alkotmány tehát az emberek, az egyének, végső soron a nép szabad akaratára vezethető vissza, mely konstituálta az államot is. Mindennek, az emberi méltóságnak az alkotmányban elfoglalt vezető helyének és a több évtized során alakított méltóság-doktrínának köszönhetően az emberi méltóságnak meghatározó ereje, iránymutató jellege van az alapjogok tartalmára, azok értelmezésére. ${ }^{5}$ Következésképpen az emberi méltóság nemcsak alkotmányos

5 A kérdésről részletesebben KuIcsu László: Az emberi méltóság a német Alkotmánybíróság egyes döntéseiben, Iustum Aequum Salutare, 2010/4, 128. Ugyanebben a lapszámban olvasható még BALOGH Zsolt Az emberi méltóság: jogi absztrakció vagy alanyi jog címú írása is. 
(legfőbb) érték, hanem sajátos alapjog, alanyi jogi tartalommal is rendelkezik, amelyből az emberi méltósághoz való jog bizonyos funkciói mutathatók ki:

„Egyrészt ez az alanyi jogi tartalom abban áll, hogy maga az állam az ember méltóságába nem avatkozhat be, vagyis az ember méltóságának az állami beavatkozást elháritó funkciója van.

Másrészt az államnak a jogalkotással és jogalkalmazással be kell avatkoznia, ha az ember méltóságát mások sértik, tehát az emberi méltóságnak védelmi dimenziója van nemcsak az állammal, hanem másokkal szemben is. Ha magánszemélyek sértik mások emberi méltóságát, az államnak kötelessége a veszélyt elháritani és a zavarást megszüntetni.

Harmadrészt akkor is be kell avatkoznia az államnak, ha az egyén nem képes a maga számára az anyagi értelemben vett méltó életet biztositani, és az anyagi létminimum alatt él, vagyis az emberi méltóságnak az Alaptörvény szerint van egy szociális igényt megalapozó dimenziója is."

Ezek tekinthetők az emberi méltósághoz való jog hagyományos funkcióinak. Ugyanakkor létezik egy sajátos, különös funkciója is, nevezetesen, hogy az Alkotmány értékrendjének, és ezen belül az alapjogok által megtestesített értékrendszernek az alapja, amiből pedig még az alkotmányos identitás megalapozása és védelme is levezethető, biztosítva ezáltal az alkotmány egységét. Ezt, mondhatni legszebben, de egyben nagy jelentőségű tudományos tartalommal fogalmazta meg Sólyom László alkotmánybíró egy párhuzamos véleményében: „Az emberi méltósághoz való jog nem puszta erkölcsi értékdeklaráció. Azt, hogy az emberi méltóság a jog előtt és felett létező érték, amely a maga teljességében a jog számára hozzáférhetetlen, nem zárja ki azt, hogy ezt az értéket a jogok forrásának tekintsük - mint a természetjogot követve számos nemzetközi egyezmény és alkotmány teszi -, vagy hogy a jog a méltóság tiszteletben tartását és védelmét elöirja, avagy egyes aktusait valóságos joggá formálja."

A román alkotmányjogi szakirodalom két referenciaértékủ alkotmány kommentárja sem tartalmaz átfogó elemzést, értékelést. Az egyik ${ }^{8}$ megelégszik az alkotmánybíráskodás kritikájával, amennyiben (egyébként joggal) elégtelennek tartja az Alkotmánybíróságnak azon közhelyszerü megállapításait, miszerint „az emberi méltóság az emberi lény elválaszthatatlan attributúma és a személy belső értéke". ${ }^{9}$ Hasonlóképpen kifogásolja, hogy más országok alkotmánybíráskodási gyakorlatától eltérően a román Alkotmánybíróság nem használta ki az emberi méltóság koncepcióját a szociális jogok védelmére, különösen a 2008-2009-es pénzügyi globális válság időszakában. A taláros testület megelégedett azzal, hogy mintegy másodlagos, szubszidiárius elemként

6 KLICSU: i. m., 127.

7 Dr. Sólyom László alkotmánybíró párhuzamos véleménye, 23/1990 (X. 31) AB határozat, ABH 1990, 88, 103.

8 Constituția României. Comentariu pe articole, ediția 2, szerk. Ioan Muraru, Elena Simina TăNăSESCU, Editura C.H. Beck, București, 2019, 16.

9 Az Alkotmánybíróság 2007/841. döntése. 
Az emberi méltóság és a személyiségi jogok összefüggései...

hivatkozzon az emberi méltóságra, a szociális állam alkotmányos fogalmából levezethető szociális jogok védelmére. ${ }^{10}$

A másik alkotmánykommentár, ${ }^{11}$ bár megkísérel egy óvatos elemzést, de átfogóbb következtetésekig nem jut el. Ennek oka talán a téves megközelítés, hiszen eleve abból az alapállásból indul ki, miszerint az alkotmány 1. cikkének (3) bekezdésében megjelölt legfőbb értékek nem mindegyikének van jogi, normatív tartalma (emberi méltóság, igazságosság), következésképpen ezek értelmének feltárása más társadalomtudományok körébe tartozik, bár - állítja a szerző - mindkettő szervesen kapcsolódik az egyénhez. Másrészt az emberi méltóság egyetemes koncepció, mely egyaránt vonatkozik az egyénre és nemzetre, kiterjesztve az állam méltóságának a tiszteletére is. Az emberi méltóságon, az alkotmány rendelkezése értelmében az egyénnek mint emberi lénynek a teljes mértékủ tiszteletét értjük a maga átfogó összetettségében, valamint a társadalmilag elfogadott, törvényileg megengedett megnyilvánulásaiban. ${ }^{12}$

Ami talán igazán fontos megállapítása, hogy a társadalmi értékrendszerben az egyes jogilag, jogi eszközökkel is védett emberi-társadalmi értékek között összetett kapcsolat, kölcsönhatás van, és egyik értéket sem tekinthetjük elszigetelten. Szoros kapcsolat van tehát az emberi méltóság és az egyén szabadsága, valamint az egyenlőség és a társadalmi igazságosság között. Az állam és annak valamennyi hatósága, de különösen a jogalkotó (parlament és kormány) köteles tiszteletben tartani és védeni ezeket az értékeket. ${ }^{13}$

\section{Az emberi méltóság viszonya a személyiségi jogokhoz}

Alkotmányjogi és polgári jogi értelemben (is) a személyiségi jogok széles köre határozható meg, bár a két jogág eltérő jogi státust és eltérő szempontú, de egymásnak nem ellentmondó, sokkal inkább egymást kiegészítő értelmezést ad. Mindenekelőtt az élethez, a testi, szellemi, lelki épséghez való jog, amely mintegy előfeltétele a személyiségnek. Az általános személyiségi jog alkotmányos alapja a román alaptörvényben egyrészt az emberi méltóság, másrészt a személyiség szabad fejlődése mint legfőbb értékeknek a biztosítása. Ahogyan az emberi méltóság fogalmának nem szentelt nagyobb figyelmet az alkotmányjogi szakirodalom, úgy a személyiség szabad fejlődésének, pontosabban alapos elemzésének még kevésbé.

Való igaz, hogy az Alkotmány 1. cikkének (3) bekezdése felsorolja a legfőbb értékeket, de nem állapít meg normatív kapcsolatot, összefüggést közöttük. Ugyanakkor bármenynyire is magától értetődő mindez, az Alkotmánybíróságnak, illetve a jogtudománynak lett volna a feladata, hogy elméletileg levezesse, tudományosan megalapozza az emberi méltóság és a személyiség szabad fejlődése közötti szerves összefüggést. Az alkotmányjogi szabályozás szintjén is megkülönböztethetők egyrészt mindazok az alapjogok, amelyek

10 Constituția României. Comentariu..., i. m., 16.

11 Constituția României. Comentarii și explicații, szerk. Cristian Ionescu, Corina Adriana Dumitrescu, Editura C.H. Beck, București, 2017, 23-24.

12 Uo., 23.

13 Uo., 24. 
a személyiség állandó, konstans, statikus elemeit védik, másrészt azok, amelyek a változó, alakuló, dinamikus részére vonatkoznak. Amikor a személyiség szabad fejlődésének biztosítását mint alapértéket határozza meg az alkotmány, akkor a személynek (mint személyiségnek) egy új koncepció szerinti jogi szabályozását, alapjogi védelmét fogalmazza meg. Ugyanis a személyiség állandó statikus elemei, mint az élethez, a testi pszichikai épséghez, integritáshoz való jog, a magánélet és családi élethez való jog, ezek védelme és tiszteletben tartása, valamint az otthon, a levelezés sérthetetlensége, illetve polgári jogi értelemben a személy jogképessége, az nevezetesen, hogy jogokkal és kötelezettségekkel rendelkezhessen, ezek mind a személy hagyományos felfogása alapján biztosított alapjogok. Az alkotmányjogi és polgári jogi felfogásban bekövetkezett változás a személyiség szabad fejlődését (kibontakozását) biztosító alapjogok, azaz a személyiség változó, alakuló, dinamikus elemeinek védelmét szolgáló alapjogok megjelenése, melyeket akár az alkotmánybírósági gyakorlat is konstituálhat.

Mindez pedig elválaszthatatlan az ember, a személyiség lényegét adó méltóságtól, hiszen valamennyi személyiségi jog, függetlenül attól, hogy a személyiség passzív avagy aktív oldalát védik, az emberi méltóságra vezethető vissza, ezek tartalmát az emberi méltóság alapozza meg. Következésképpen a személyiség statikus és dinamikus elemei együttesen, az ezekhez köthető alapjogok védik az egész személyiséget, az emberi lét teljességét az élet minden területén. A személyiség szabad fejlődéséből az általános cselekvési szabadságot, míg a személyiség statikus részéből az általános személyiségi jogok körét lehetne levezetni, mégpedig az alkotmányossági normakontroll keretében kialakított alkotmányértelmezéssel.

Az alkotmánynak a legfőbb értékekre vonatkozó rendelkezései, különös tekintettel az emberi méltóságra, a személyi szabadság fejlődésére, valamint az igazságosságra, akkor kelhetnek életre, válhatnak az alkotmányos jogrendszer eleven, alkalmazott princípiumaivá, ha ezek tartalmát, értelmét az Alkotmánybíróság állapítaná meg elvi értékủ és jelentőségű, általánosan kötelező döntéseiben. Természetesen fontos, hogy az alkotmányban szereplő személyiségi jogokat ne keverjük össze mindazon polgári jogi személyiségi jogokkal, melyek bizonyos esetekben még megnevezésükben is azonosak, de előzőek az általános személyiségi jogok körébe tartoznak magasabb (legmagasabb) szintű jogi védelemmel, míg az utóbbiak egyszerủ jogági jogok szintjén helyezkednek el, és az ennek megfelelő jogi védelemben részesülnek.

Az általános személyiségi jogok alkotmányi körébe tartoznak, a fennebb már említett jogokon kívül, a személyi szabadság és a személyi biztonság sérthetetlensége, az általános cselekvési szabadság, a mozgásszabadság, az önazonossághoz és ezen belül a nemzeti kisebbségek identitáshoz való joga.

A személyiség szabad fejlődését biztositó alapjogok körébe sorolhatók értelemszerủen az oktatáshoz, képzéshez való jog, a kultúrához való hozzáférés, az információs önrendelkezési jog, a személy testi, egészségügyi önrendelkezési joga, a lelkiismereti szabadság, a kifejezés szabadsága, a saját arculathoz (képmáshoz) való jog, a házasságkötés szabadsága és a perbéli önrendelkezési jog.

Valószínű, hogy ez a felsorolás nem teljes. Egyes jogok nevesítettek a román Alkotmányban, másokat esetgyakorlati hivatkozások és értelmezések miatt említettem. Az azonban bizonyos, hogy ezek mindegyike az emberi méltóság által megalapozottak, 
Az emberi méltóság és a személyiségi jogok összefüggései...

még akkor is, ha ennek jogdogmatikai értékelését az Alkotmánybíróság nem végezte el. Ilyen módon például az általános cselekvési szabadságot, mint a személyes szabadság elengedhetetlen velejáróját, az Alkotmánybíróság megfogalmazta, de nem bontotta ki, nem elemezte, nem alapozta meg átfogó értékelés keretében. Az emberi méltóság, amenynyiben alanyi jogként lenne elfogadva és értelmezve, egyszersmind maga is általános személyiségi jogként jelenne meg, akár olyan szubszidiárius jogként, melyre közvetlenül is hivatkozni lehetne „az egyén autonómiájának védelmére, ha az adott tényállásra a konkrét nevesített alapjogok egyike sem alkalmazható”. ${ }^{14}$

\section{Korlátozhatatlan és korlátozható személyiségi jogok. Örökkévalósági klauzula}

A személyiségi jogok közül egyesek olyan mértékben sérthetetlenek (érinthetetlenek), hogy még törvény útján sem korlátozhatók. Ilyen a román alkotmányban az élethez való jog, valamint a személy testi és pszichikai integritásához, épségéhez való jog. Ennek következtében tilos a halálbüntetés, és senkit nem lehet kínzásnak vagy bármiféle embertelen vagy lealacsonyító büntetésnek, kezelésnek alávetni. ${ }^{15}$ Hasonlóképpen az igazságszolgáltatáshoz való szabad hozzáférést, annak jogát, hogy bárki bírósághoz forduljon jogainak, szabadságainak, törvényes érdekeinek a megvédéséért, egyetlen törvény sem korlátozhatja. ${ }^{16}$

Főszabály szerint azonban lehetőség van az egyes alapvető jogok és szabadságok korlátozására, még azokéra is, amelyeket az alkotmány sérthetetlennek nyilvánít. İgy például sérthetetlen a személyi szabadság, a személyi biztonság, az állandó lakhely és a lakás, a levelezés titkossága, a lelkiismereti szabadság (a gondolatok, a vélemények, a vallásos hitek szabadsága), a kifejezés szabadsága, az információhoz való jog. Más jogok esetében az alkotmány a biztosított, garantált kifejezést használja, mint például a tanuláshoz való jog, a kultúrához való hozzáférés, az egészség oltalmához való jog, örökösödési jog stb. A többi alapjog pedig megfogalmazásakor az alkotmányozó nem használta sem a sérthetetlen, sem a garantált kifejezéseket, de ez természetesen nem jelenti azt, hogy ne rendelt volna melléjük garanciákat, eszközöket érvényesíthetőségükre. Gondolok itt a politikai jogok, a gyülekezési jog, a sztrájkjog gyakorlására. A legfőbb garancia, különösen a személyiségi jogok védelmére, hogy ezek gyakorlása kizárólag csak törvénnyel korlátozhatók, mégpedig ha egy demokratikus társdalom feltételei között szükséges, az arányosság követelményét tiszteletben tartva és anélkül, hogy ezek a korlátozások maguknak az alapjogoknak a létét érintené. ${ }^{17}$

Végül az alkotmány örökkévalósági klauzulája előírja, hogy az alapjogok, szabadságjogok semmiféle olyan megváltoztatása nem lehetséges, amely ezek, illetve ezek

ZAKARIÁs Kinga: i. m., 179.

Mindezeket a román Alkotmány 22. cikke szabályozza.

6 Az Alkotmány 21. cikkének (1) és (2) bekezdései szabályozzák.

17 Az Alkotmány 53. cikke szabályozza. 
biztosítékainak a megszüntetésére irányulna. ${ }^{18}$ Miközben úgy általában vitatható az örökkévalósági klauzula, különösen azon része, amely az államra, államszervezetre, hivatalos nyelvre vonatkozik, ${ }^{19}$ az azért szembeötlő, hogy az alkotmányos legfőbb értékek közül a talán legfontosabb három - az emberi méltóság, a személyiség szabad fejlődése és az igazságosság - nem szerepel a megváltozhatatlan rendelkezések között abban az értelemben, hogy egy jövőbeni alkotmányozó hatalom sem mondhatna le ezekről a legfőbb értékekről.

\section{A román Polgári törvénykönyv szabályozása}

\subsection{Koncepcióváltás}

A régi, 1864-es Polgári törvénykönyv a magánjogi szabályozások dualista felfogását vallotta és valósította meg azáltal, hogy külön szabályozta a tulajdonképpeni polgári jogi viszonyokat, és ettől eltérően a kereskedelmi jogi viszonyokat. Ennek a dualista felfogásnak az eredményeként született meg 1887-ben a román Kereskedelmi törvénykönyv.

A magánjog XIX. századi dualista felfogásától teljesen idegenül, a szovjet típusú szocialista jog hatására a román kommunista törvényhozó valójában szétzilálta (bár hatályon kívül nem sikerült helyeznie) a román Polgári törvénykönyvet azzal, hogy több szabályozási területet kiemelt a kódexből, és külön törvénykönyvet vagy jogszabályt alkotott. Így került elfogadásra az 1958-as Családi törvénykönyv, a természetes személyekről és jogi személyekről szóló 1954. évi 31-es számú, és az elévülésről szóló 1954. évi 167-es számú rendelet, melyek egyébként nagy jelentőségủek voltak a korszak magánjogi viszonyainak rendezésében.

Az új, immáron monista felfogású Polgári törvénykönyv azonban mindezeket a szabályozási tárgyköröket, beleértve a kereskedelmi jogi, valamint a nemzetközi magánjogi jogviszonyok szabályozását, részben ismételten magába olvasztotta. ${ }^{20} \mathrm{~A}$ monista fordulaton túl azonban a jogalkotó jelentős korszerüsítéseket végzett, vagy éppen átfogó reformokat is bevezetett a magánjogi jogviszonyok szabályozásába. Ezek közül kiemelkedik koncepcionális újszerủségével a személyiségi jogok polgári jogi szabályozása.

Bár elsődlegesen a személyiségi jogok az alkotmányban kerülnek szabályozásra, ugyanakkor a társadalmi viszonyok változása, az új problémák, kihívások megjelenése, de még a technikai fejlődés is szükségessé teszik az alaptörvényi szabályozásokon túl a konkrétabb polgári jogi szabályozásokat is. Ezzel pedig a törvényhozó nem valamilyen jogi, szabályozási divatnak próbált megfelelni, hanem valóságosan jelentkező új problémákra kívánt reagálni, és megfelelő normatív megoldásokat találni, illetve adni.

18 Az Alkotmány 152. cikkének (2) bekezdése.

19 Az Alkotmány 152. cikkének (1) bekezdése.

20 A kérdésről részletesen VEREsS Emőd: A román magánjog fordulópontjai = Román polgári törvénykönyv, Forum Iuris Könyvkiadó, Kolozsvár, 2017, 1-9. 
Az emberi méltóság és a személyiségi jogok összefüggései...

\subsection{A személyiségi jogok polgári jogi szabályozásának szerkezete}

Az Rptk. „A személyekről” szóló I. könyve értelemszerủen külön tárgyalja a természetes személyeket és a jogi személyeket. A természetes személyekre vonatkozó polgári jogi rendelkezések egyrészt követik a hagyományos szabályozási tárgyköröket: a természetes személy jogképessége, cselekvőképessége, név, lakhely, családi állapot alapján történő azonosítása, valamint a természetes személy polgári jogi védelme.

Ebbe a klasszikusnak számító és egyben kötelező szabályozási körbe illeszkedik, mintegy beékelődik a természetes személyekről szóló I. cím II. fejezeteként egy, a korábbi szabályozásokhoz (beleértve nemcsak a szocialista jogfelfogást, de az azt megelőző, az 1864-es Rptk. eredeti változatát is) képest teljesen újszerủ és új koncepciókon alapuló szabályozási terület. Már a fejezet szokatlan címe: „Az emberi lény és veleszületettjogainak tiszteletben tartása" is jelzi, hogy itt valami teljesen újszerủ jogok szabályozásáról van szó. A természetes személyről szóló II. cím ezen második fejezete négy szakaszban, az 58-81. cikkekben szabályozza lényegében a személyiségi jogokat.

A közös rendelkezésekben mintegy felsorolja a személyiségi jogokat, a második szakasz a természetes személy élethez, egészséghez és testi épséghez való jogát írja elő, különös tekintettel az emberi test sérthetetlenségére, a genetikai jellemzők vizsgálatának, módosításának korlátozására vagy éppen tilalmára, a különböző orvosi beavatkozások, szervátültetések szabályozására. A fejezet harmadik szakasza „a magánélet és a személy méltóságának tiszteletben tartásá"-ról szól, az ezzel összefüggésben nevesített jogokról és azok védelméről. Végül a negyedik szakasz a halottnak járó tiszteletről mint sajátos személyiségi jog sajátos megnyilvánulási formája, illetve ennek ugyancsak sajátos személyiségi jogvédelme.

Ez tehát a szerkezete a Polgári törvénykönyv azon, a személyiségi jogokról szóló fejezetének, amely korábban semmilyen formában nem létező szabályozásokat vezet be, és amely teljesen új alapokon, megközelítésben és felfogásban értelmezi a természetes személyt, túlmutatva vagy pontosabban kiterjesztve annak jogalanyiságát azáltal, hogy az egyént, a maga összetett, többrétegủ valóságában, személyiségként fogja fel, és a személyiség jogait határozza meg.

A következőkben a közös rendelkezéseken túl, mely mintegy a személyiségi jogok taxatív felsorolását tartalmazza, kizárólag a magánélet és a személy méltóságának tiszteletben tartásáról szóló szakasz néhány aspektusát elemzem.

\subsection{A nevesített személyiségi jogok és ezek jogi természete}

Az említett közös rendelkezések három cikke közül csak az első, az 58-as cikk használja a személyiségi jogok megnevezést. A következő két cikk egyrészt az egyén, a természetes személy azonosító elemeit, másrészt a személy önrendelkezési jogát határozza meg. Az azonosító elemek lényegében a hagyományos szabályozást tartalmazzák, hiszen utalnak azokra az identitást meghatározó (nevezhetnénk technikai) elemekre, mint amilyen a névhez, a lakhelyhez, tartózkodási helyhez, valamint a családi állapothoz való jogok. Ezek arra szolgálnak, hogy egyrészt az egyén beazanosítható legyen a 
társadalomban, a társadalom tagjai között, továbbá a térben, hiszen állandó lakhelye és/vagy tartózkodási helye révén biztosított jogi, adminisztratív elérhetősége (tehát ezen jog nem a lakhatási jogot jelenti), és végül az egyén azon jogát, hogy családi állapota jogi elismerést kapjon.

Ezek, meglátásom szerint, ugyancsak személyiségi jogok, és az emberi méltóságra vezethetők vissza, hiszen e jogok bármelyikének megsértése az emberi méltóság súlyos megsértését is jelenti. Természetesen ezen jogok gyakorlása a törvény feltételei, adott esetben korlátozásai keretében történhet, nem lévén abszolút jogok. Például a névváltoztatás csak bizonyos indokolt esetben történhet. A lakhely megválasztása bár szabad, de a törvény előírásai szerint kell történjen. A családi állapot részben lehet ténybeli adottság (például valaki özvegy), de lehet szabad akarat megnyilvánulása is (valaki házas vagy elvált).

Az Rptk. 60. cikkében rögzített önrendelkezési jog az Alkotmány 26. cikke (2) bekezdésének szó szerinti átvétele. ${ }^{21}$ Konkrét, valós tartalmat a rendelkezésnek csak az Rptk. 68. cikke (1) bekezdése ad, nevezetesen a szerv-, szövet-, illetve sejtdonorok esetében, melynek során szükséges a donornak az írásos, szabad előzetes és kifejezett beleegyezése az eljáráshoz. ${ }^{22}$ Ugyanakkor mind az alkotmányi, mind a polgári jogi szabályozás a személy önrendelkezéséről ennél sokkal tágabb és bővebb, akkor is, ha sem az alkotmányozó, sem a törvényhozó nem fogalmazta meg a konkrét, lehetséges önrendelkezés eseteit, ami egyébként meglehetősen nehéz is lenne.

Az Rptk. 58-as cikke a következő személyiségi jogokat sorolja fel: az élethez, az egészséghez, a testi és lelki épséghez való jog, a méltósághoz való jog, a saját képmáshoz való jog, valamint a magánélethez való jog (a magánélet tiszteletben tartása). A cikk nyitva hagyja a személyiségi jogok körét azzal a nem túl pontos megfogalmazással, hogy hasonló jogokat a törvény elismerhet.

A törvénykönyv ezen rendelkezése a kommentárok véleménye szerint nem lezárt felsorolás, hiszen más jogok, alapjogok is tekinthetők személyiségi jogoknak, elsősorban a szabadságjogok, konkrétan pedig a lelkiismereti szabadság, a vallásszabadság, a kifejezés szabadsága, a mozgásszabadság. ${ }^{23}$ Ugyanakkor ebbe a szélesebb körbe sorolhatók Az emberi jogok európai egyezségokmánya által megnevezett jogok és szabadságjogok, mint amilyen a gondolatszabadság (9. cikk), a házassághoz való jog (12. cikk), a méltányos igazságszolgáltatáshoz való jog (6. cikk) vagy az embertelen és lealacsonyító bánásmód tilalma.

A személyiségi jogok jogi természetét illetően ezek alapvetően nem vagyoni jellegü jogok, ennek minden jellemzőjével, ugyanakkor megfigyelhető olyan jelenség is, amely a közelmúltban vált egyre inkább elterjedtté, hogy bizonyos személyiségi jegyek,

${ }^{21}$ Az Alkotmány 26. cikkének (2) bekezdése, melyet átvesz az Rptk. 60. cikke, a következőket írja elő: „A természetes személynek joga van önmagáról rendelkezni, amennyiben nem sérti mások jogait és szabadságait, a közrendet vagy a közerkölcsöt.”

22 Az Rptk. 68. cikkének (1) bekezdése: „Élő donortól származó emberi eredetü szervek, szövetek és sejtek eltávolitása és átültetése kizárólag a törvényben elöirt esetekben és feltételek között történhet, annak irásos, szabad, elözetes és kifejezett beleegyezésével, és csak miután a beavatkozás kockázatairól elözetesen tájékoztatták. Minden esetben a donor az eltávolitás időpontjáig visszavonhatja beleegyezését." ${ }_{23}$ Noul Cod Civil. Comentariu pe articole, szerk. Flavius-Antoniu BAIAs, Eugen Chelaru, Rodica Constantinovici, Ioan Macovei, Editura C.H. Beck, București, 2014, 72. 
mint amilyen a saját képmás, saját hang, név vagy akár a magánélet különböző részei, el egészen az intimebbnek tekinthető szféráig is kiaknázható, szerződéses megállapodás keretében mintegy „értékesíthető”. Tehát bizonyos vagyoni tartalommal is járhat a személyiségi jogok gyakorlása, aminek következtében ezek jogi természetük alapjait meghatározó nem vagyoni jellegük nem tekinthetők abszolút érvényủnek. ${ }^{24}$

A személyiségi jogok jogi természetére vonatkozóan lényegében a hagyományosnak tekinthető, személyhez füződő nem vagyoni jellegű alanyi jogok jellemzői, elvei érvényesek, úgymint:

a) az átruházhatatlanság elve, azaz nem válhatnak hagyaték tárgyává, hiszen olyan mértékben az egyént, a konkrét természetes személyt illetik, hogy haláluk után ezek megszünnek;

b) az engedményezhetetlenség elve, ami azt jelenti, hogy nem képezhetik jogügyletek tárgyát, és nem köthető vonatkozásukban semmilyen érvényes szerződés;

c) a követhetetlenség elve, mely szerint nem lehet kényszervégrehajtás útján a hitelezők igényeinek kielégítése céljából folytatott végrehajtás tárgyává tenni;

d) a közvetlen gyakorlás elve, azaz e jogok olyan mértékben kötöttek a személyhez, hogy gyakorlásuk csak közvetlenül történhet, mely kizárja a megbízás, megbízott közvetítőn keresztül történő gyakorlás lehetőségét;

e) az elévülhetetlenség elve azt jelenti, hogy e jogok nem évülnek el, akár az adott személyiségi jog gyakorlásának hiányában sem, és más személy nem szerezheti meg elbirtoklás útján;

f) az érvényesíthetőség elve biztosítja a személyiségi joggal rendelkező számára, hogy bármely jogalannyal szemben érvényesíthesse. ${ }^{25}$

\subsection{A magánélet és a személy méltóságának tisztelete}

A fenti alcím azonos az Rptk. Személyekről szóló I. könyv II. címének 3. szakaszával, és a 70-77. közötti cikkeket foglalja magába. Ez azonban annyiban megtévesztő, hogy a magánélethez való jog (71. cikk) és a méltósághoz való jog (72. cikk) mellett külön rendelkezik a szabad véleménynyilvánításhoz való jogról (70. cikk), a saját képmáshoz való jogról (73. cikk) valamint részletesen szabályozza a magánélet megsértésének eseteit (74. cikk), illetve a korlátozásokat, a beleegyezés vélelmét és a személyi jellegủ adatok feldolgozását (75-77. cikekben).

Természetesen ezek mindegyike és különösen a konkrét személyiségi jogok szoros összefüggésben és kölcsönhatásban vannak egymással. Ezek, az előző részben felsorolt személyiségi jogokkal együtt pedig elválaszthatatlanul kötődnek az emberi méltósághoz mint „anyajoghoz”, e jogok forrásához, még akkor is, ha a román alkotmány nem tételezi jogként az emberi méltóságot. A méltósághoz való jog azonban megjelenik az Rptk. 72-es cikkében, melynek (1) bekezdése előírja, hogy minden személynek jog van méltóságának tiszteletben tartására. A (2) bekezdés pedig azt, hogy tilos bármilyen

24 Sztranyiczki Szilárd, Kokoly Zsolt: Román polgári jog. Személyek, Forum Iuris Könyvkiadó, Kolozsvár, 2021, 40.

25 Uo., 40-41. 
módon megsérteni valamely személy becsületét és jó hírnevét annak beleegyezése vagy a 75. cikkben foglalt korlátozások tiszteletben tartása nélkül.

Ez a szabályozás tulajdonképpen további részletezése, kibontása az Alkotmány 30. cikke (6) bekezdésének. A 30. cikk a kifejezés szabadságáról szól, és a 8 bekezdésből csak az (1) fogalmazza meg magát az alapjogot, a többi további hét tiltásokról szól. Közöttük a (6) bekezdés, mely elöírja, hogy „a kifejezés szabadsága sértheti meg a személy méltóságát, becsületét, magánéletét és saját arculatához való jogát”. Ennek az alkotmányi rendelkezésnek a fényében már jobban érthető az Rptk. „A magánélet és a személy méltóságának tiszteletben tartása" címmel ellátott része.

A polgári jogi szabályozás ezzel kapcsolatban használhatja ugyan a méltósághoz való jog kifejezést mint adott személyiségi jogot, de ebben az összefüggésben nincs köze az emberi méltósághoz való jog azon elméleti megközelítéséhez, amit a német és magyar alkotmánybírósági értelmezések és szakirodalom kidolgoztak. Mintegy sajátos, némileg paradox fogalomhasználattal a méltósághoz való jog polgári jogi fogalma mint a kifejezés szabadságának egy sajátos esete jelenik meg, és mint ilyen természetesen kötődik az emberi méltóság alkotmányi alapértékéhez mint forráshoz.

Másképpen fogalmazva: a kifejezés szabadsága mint alkotmányos alapjog kapcsán előírt tilalmak, korlátok, mely szerint ennek gyakorlása nem sértheti a személy méltóságát (továbbá becsületét, magánéletét és saját arculathoz való jogát), majd ennek polgári jogi részletesebb szabályozása nem teremti meg az emberi méltóság, illetve az emberi méltósághoz való jog normatív, alanyi jogi tartalmát. Sokkal inkább fogalmi zűrzavart kelt, hiszen az Rptk. 72-es cikkének (2) bekezdése a méltósághoz való jogot, egyébként érthetően, az adott alkotmányi szövegkörnyezetre, a becsület és jó hírnév védelmére korlátozza. Csakis így érthetô és magyarázható, hogy miért nem részei a méltósághoz való jognak a magánélethez való jog, a szabad véleménynyilvánításhoz való jog és a saját képmáshoz való jog, miközben a becsület és (a jó hírnév) és csakis ezek, úgy tűnik, hogy részei. Az Rptk. 72-es cikke erre enged következtetni.

A törvényszöveghez füzött kommentár is ezt támasztja alá, mely kijelenti, hogy a méltósághoz való jog tartalma a becsület és a személy jó hírneve. A két fogalmat elemezve a kommentár szerzője elismeri, hogy meglehetősen nehéz a becsület és a jó hírnév közötti határvonalat meghúzni, ezért talán inkább a méltósághoz való jog két megjelenési formájának, semmint két önálló alkotóelemének lehetne tekinteni. ${ }^{26}$

A jogi szakirodalom próbálkozott a két fogalom meghatározásával is. Eszerint a becsület egy összetett érzés, mely a minden személyben kialakult saját méltóságára vonatkozó felfogás által meghatározott, valamint mások percepciója az ő méltóságáról. ${ }^{27}$ Egy másik megállapítás szerint a becsületnek nemcsak egyéni, individuális jellege van, hanem hangsúlyosan társadalmi jellegủ is, melyből szoros kapcsolata adódik a jó hírnév fogalmához, és amely akár a fogalmi azonosságig is elmehet, amennyiben a jó hírnév megsértése egyben a becsület megsértését is jelenti. ${ }^{28}$

26 Noul Cod Civil..., i. m., 88.

27 Uo. A kommentár szerzője idézi a francia szakirodalomból Philippe MALAURIE, Laurent AynÈs: Les personnes. Les incapacités, Ed. Cujas, Paris, 1999, 162.

28 Ovidiu Ungureanu, Cornelia MunTeanu: Drept civil. Persoanele, în reglementarea noului Cod civil, Editura Hamangiu, București, 2013, 66. 
Az emberi méltóság és a személyiségi jogok összefüggései...

Az elemzésben megfogalmazott következtetés arra korlátozódik, hogy egyrészt az alkotmány, bár az emberi méltóságot legfőbb értéknek tekinti, melyet az államnak garantálnia kell, és bár az emberi méltósághoz való jogot alanyi jogként nem rögzíti, ugyanakkor számtalan alapjogi szabályozás révén, közvetett módon mégiscsak az emberi méltóságot védi. Másrészt pedig a polgári jogi szabályozás az új Rptk.-ban, a 72. cikkben, az Alaptörvény 30-as cikke (6) bekezdésének alkalmazásaként megfogalmazza ugyan a méltósághoz való jogot, de még az alkotmányi rendelkezésnél is szűkebb, korlátozottabb jelentéssel és tartalommal.

Az alkotmányozó, majd a törvényhozó kétségtelenül nagy előrelépéseket tett a személy fogalmának átértékelésében, eljutva a jogképesség intézménye által meghatározott (egyébként elengedhetetlenül szükséges) jogi absztrakciótól a személyiségként felfogott személy rendkívül komplex helyzetének, állapotának az elismeréséhez, amelyhez azonban már új fogalmi készlet használata szükséges. Ezek az alkotmányjogi és polgári jogi szabályozások minden bizonnyal a legjobb szándék által vezérelve születtek meg, de nem biztosítanak kellő koherenciát a megfelelő alkalmazáshoz és értelmezéshez. Ezt a hiányosságot pótolni az Alkotmánybíróság lett volna hivatott, de mindmáig elmulasztotta, nem ismervén fel lényegében a „tálcán kínált” fogalmakban (úgymint emberi méltóság, a személyiség szabad fejlődése, a személyiségi jogok és ezek összefüggéseiben) rejlő potenciált ezek megfelelő értelmezésére, tudományos, jogdogmatikai megalapozására.

\section{Az Alkotmánybíróság gyakorlata}

Elöljáróban az alkotmánybírósági gyakorlat néhány elvi jelentőségű megállapítását idézném. Egyik döntésében a román Alkotmánybíróság megfogalmazta, hogy „az emberi méltóság a személy elidegenithetetlen attribútuma, az emberi lény belső értéke" ${ }^{29} \mathrm{~A}$ taláros testület kialakult gyakorlata, hogy nem tekinti önálló jognak az emberi méltóságot, hanem az alkotmányi rendelkezéseknek megfelelően a jogállam egyik legfőbb értékének, illetve vezérlő alapelvnek. Azt azonban elismeri, hogy az állampolgárok jogai és szabadságjogai hasonlóképpen alkotmányos alapértékek, amelyek az emberi méltóságon és a személyiség szabad fejlődésén alapulnak. ${ }^{30}$

Az Alkotmánybíróság, azzal a szándékkal, hogy átvegye és igazodjon a német Szövetségi Alkotmánybíróság referenciaértékủ és releváns gyakorlatához, arra az álláspontra jutott, hogy nemcsak az emberi méltóság jelenti az alapjogok forrását, ugyanis „a személyiség szabad fejlődésével” összefüggésben ennek van egy passziv és egy aktív része. A passziv rész vonatkozásában a személyiség szabad fejlődése, közvetlen, elválaszthatatlan kapcsolatban az emberi méltósággal, elvezet az általános személyiségi jogokhoz, e jogok védelméhez, aktív része pedig nem kizárólag az emberi méltóságon alapszik,

\footnotetext{
29 Az Alkotmánybíróság 2011/1576. döntése, megjelent: Románia Hivatalos Közlönye, 2012. január 16, 32. sz.

30 Az Alkotmánybíróság 2009/1109. döntése, megjelent: Románia Hivatalos Közlönye, 2009. október 9, 678. sz.
} 
és a személy általános cselekvési szabadságában jut kifejezésre. Példaként említhető a gazdasági tevékenység szabadsága.

Ennek alapján a román alkotmánybírósági esetgyakorlatból egy olyan koncepció körvonalazódását lehet felfedezni, mely az emberi jogok „forrásvidékét” három csoportra osztja. Eszerint: a) az alapvető jogok egy részének alapja kizárólag az emberi méltóság, b) az általános személyiségi jogok az emberi méltóságon és a személy szabad fejlődésének követelményén alapulnak, c) a személy általános cselekvési szabadsága pedig elsődlegesen a személy szabad fejlődésén. Mindezek alapján az Alkotmánybíróság nem zárja ki, hogy az emberi méltóság fogalmából, tartalmából olyan alapjogok is levezethetők legyenek, amelyek egyébként nincsenek tételesen megfogalmazva az Alkotmányban. ${ }^{31}$

Az emberi méltóságra vonatkozó alkotmánybírósági felfogásnak bizonyos változásaként, fejlődéseként értékelhetjük azt, amikor egyik döntésében kifejti, hogy az emberi méltóság fogalma mint alkotmányos alapérték nemcsak egyszerü kinyilatkoztatás, hanem önálló normatív tartalommal rendelkező sajátos alapvető jog. Ebből következően az alapjogok megsértése az emberi méltóság közvetett megsértését is jelenti, hiszen az előbbiek fundamentuma az utóbbiban van. Ugyanakkor az emberi méltóság közvetlen (a többi alapjogtól függetlenül) megsértése is megállapítható és szankcionálható, éppen azon oknál fogva, hogy normatív értékkel rendelkező, önálló alapjog. ${ }^{32}$

Egy másik döntésében a személyiségi jogok egy külön területére, a személyi adatok védelmére, ezen belül pedig az orvosi/egészségügyi adatok védelmére vonatkozóan nyilvánított alkotmányellenesnek olyan törvényi rendelkezéseket, ${ }^{33}$ amelyek sértették ezen személyiségi jogokat. ${ }^{34} \mathrm{E}$ döntésében (is) a német Szövetségi Alkotmánybíróság gyakorlatára hivatkozott, amikor megfogalmazta, hogy a törvényhozónak kötelessége biztosítania a családi és magánélethez, valamint az intimitáshoz való jog érvényesülését, és garanciákat kell nyújtania ezek védelmére. A konkrét esetre alkalmazva megfogalmazta, hogy a törvényhozó a jogszabályi rendelkezésekben nem kötheti olyan feltételhez az egészségügyi szolgáltatási ellátást, mint az elektronikus egészségügyi nyilvántartásba történő bejelentkezést. Az érintett személy szabad beleegyezése folytán közölhet egészségügyi állapotára vonatkozó személyes adatokat, melyeket feldolgozhatnak, de azokat is, akik úgy döntenek, hogy nem közölnek ilyen adatokat és nem egyeznek bele ezek feldolgozásába, ugyanolyan egészségügyi, orvosi ellátásban kell részesíteni. Ez esetben a román Alkotmánybíróság hivatkozott a német Szövetségi Alkotmánybíróság döntésére, ${ }^{35}$ illetve azon kidolgozott koncepciójára, mely szerint az egyén semmilyen körülmények között nem lehet tárgya valamely szabályozásnak vagy intézkedésnek, hanem csak alanya. A Nép Ügyvédje által kezdeményezett utólagos absztrakt normakontroll keretében

\footnotetext{
31 Minderről részletesebben lásd ZaKARIÁs Kinga, BENKE Károly: Demnitatea umană în jurisprudența instanțelor constituționale din Germania, Ungaria și România, Buletinul Curții Constituționale, 2012/2, 58-59.

32 Az Alkotmánybíróság 2019/465. döntése, megjelent: Románia Hivatalos Közlönye, 2019. augusztus 8, 645. sz.

33 A 2006. évi 95. törvény az egészségügyi reformról - a 30. cikk (2) és (3) bekezdésében, valamint a 280. cikk (2) bekezdésében „a beteg elektronikus egészségügyi dossziéjának a rendszere” kifejezés.

34 2018/498. döntés, megjelent: Románia Hivatalos Közlönye, 2018. július 26, 650. sz.

35 BVerfGE 45, 187.
} 
az alkotmányellenesnek minősített rendelkezések nem nyújtottak megfelelő speciális védelmet és garanciát sem a személy egészségügyi adatai vonatkozásában, különösen, hogy ezen adatok közlési, tárolási és feldolgozási módozatának szabályozását, a felelősségeket és a szankciókat másodlagos normákhoz utalta, holott ezeket a törvénynek kellett volna szabályoznia.

Az Alkotmánybíróság másik döntése egy igencsak érzékeny kérdést érint, és már csak azért is érdemes bemutatnunk, mert alkotmányellenesnek minősített egy alapvetőnek számító polgári jogi rendelkezést. Megjegyzendő, hogy az elmúlt évtizedben az Alkotmánybíróság csak ebben az egy esetben, az Rptk. egyetlen cikke tekintetében állapította meg az alkotmányellenességet.

Az utólagos alkotmányossági normakontroll keretében a kereset szerzője az Rptk. 164. cikk (1) bekezdését kifogásolta, mivel szerinte a rendelkezés egy sor alkotmányi és nemzetközi jogi elöírást sért.

A 164. cikk (1) bekezdése értelmében „Az a személy, aki elmebetegség vagy gyengeelméjüség miatt nem rendelkezik megfelelő itélőképességgel, hogy saját érdekeirool gondoskodjon, bírósági gondnokság alá helyezendő”. Ez a polgári jogi rendelkezés „A bírósági gondnokság alá helyezett személy védelme" címü fejezetében szerepel, mely fejezet a bírósági gondnokság alá helyezés jogintézményét, annak feltételeit szabályozza. ${ }^{36}$

Magát az eljárást pedig a Polgári eljárási törvénykönyv vonatkozó rendelkezései szabályozzák. ${ }^{37} \mathrm{Az}$ említett törvényi előírások, szabályozások lényegében nem módosultak a korábbiakhoz képest, ami azt jelenti, hogy a korábbi Családjogi törvénykönyv és az 1954. évi 31., a természetes személyekről és jogi személyekről szóló törvényerejü rendelet előírásait vette át az új Rptk.

A kereset szerzője az alkotmányossági kifogásban (törvényes gyámja és jogi képviselője révén) azt fogalmazta meg, hogy a kérdéses rendelkezés többek között nem kellően pontos és világos, diszkriminatív, sérti a személyes szabadságot és az igazságszolgáltatáshoz való szabad hozzáférést, a munkához és a tulajdonhoz való jogot, valamint a fogyatékos személyek védelméről szóló alkotmányos rendelkezést. ${ }^{38}$ Hasonlóképpen azt is kifogásolta, hogy a rendelkezés nincs összhangban több nemzetközi jogi jogszabállyal sem.

Konkrétan a kifogás arra utal, hogy a gondnokság alá helyezés jogintézménye egy olyan merev különbségtételre utal, mely az ítélőképességgel rendelkező és az ítélőképességgel nem rendelkező személyek között áll fenn, kizárva lényegében annak lehetőségét, hogy létezhetnek olyan személyek, akiknek az ítélőképesség hiánya átmeneti vagy részleges, vagy éppen csökkent, részleges ítélőképességgel rendelkeznek.

A törvényi rendelkezés tehát nem teszi lehetővé az eljárást elrendelő bírói hatóság számára az egyénre, az egyéni helyzetre és szükségletekre szabott intézkedést. Továbbá pontatlan, illetve nincs meghatározva a törvény szövegében „a saját érdekeiről gondoskodjon” kifejezés. Mindezek miatt a kereset szerzője szerint a bírósági gondnokság alá

36 Az Rptk. 164-177. cikkei.

37 A Polgári eljárási törvénykönyv 936-943. cikkei.

38 Ezek a kifogások a következő alkotmányi rendelkezésekre utalnak: 1. cikk (5) bekezdés, 16. cikk (1) bekezdés, 23. cikk (1) bekezdés, 21. cikk, 41. cikk, 44. cikk, 50. cikk. 
helyezés aránytalan és indokolatlan beavatkozást jelent a személy alapvető jogaiba, és lehetetlenné teszi a társadalmi beilleszkedését.

Az Alkotmánybíróság a normakontroll során megállapította, hogy a bírósági gondnokság alá helyezés jogintézménye az érintett személy védelmét szolgálja, melyre jogainak és vagyoni, valamint nem vagyoni érdekeinek védelméért kerül sor, előzetes orvosi vizsgálat alapján. Ugyanakkor minden, a személy jogainak/érdekeinek védelmére vonatkozó rendelkezés arányban kell hogy legyen a személy képességeivel, megfelelve élethelyzetének, figyelembe véve a személy akaratát és azt, hogy más intézkedések nem nyújtanak számára kellő védelmet, illetve hogy az intézkedés a lehető legrövidebb időre szóljon, rendszeres felülvizsgálat mellett. ${ }^{39}$

Az Alkotmánybíróság megállapította, hogy az Rptk. abból a (hibás) értékelésből indul ki, hogy a szellemi képesség bármilyen lehetséges sérülése, függetlenül ennek fokától, a jogi cselekvőképesség teljes elvesztését jelenti. Ez a szemlélet pedig teljesen eltér A fogyatékos személyek jogairól szóló egyezménytől, melyet egyébként Románia ratifikált..40

A jogi cselekvőképesség elvesztése rendkívül súlyos következményekkel jár a személyre nézve, ezért megfelelő jogi garanciák szükségesek az egyén jogainak védelme érdekében. Következésképpen a cselekvőképesség szükségesnél nagyobb korlátozása az érintett személyt hátrányos helyzetbe hozza a többi személlyel szemben, sértve az egyenlőség alapelvét, hiszen megfosztja a még tudatos akarat és cselekvés szabadságától. Tekintettel arra, hogy a fogyatékosság különböző fokai, fokozatai léteznek, a személy ítélőképessége pedig kisebb vagy nagyobb mértékben lehet sérült, anélkül, hogy teljesen hiányozna, következésképpen mielőtt a legsúlyosabb intézkedést, a gondnokság alá helyezést elrendelnék, kevésbé korlátozó alternatív intézkedésekre van szükség. Ezeket a törvényhozónak kell megfogalmaznia, azonban a jelenlegi polgári jogi rendelkezésekből hiányoznak. Következésképpen a bírósági gondnokság alá helyezést ultima ratio jellegü szabályként kell alkalmazni. ${ }^{41}$

A taláros testület megállapította, hogy sem az intézkedés időtartamára, sem az időszakos felülvizsgálatára vonatkozó törvényi rendelkezések nincsenek összhangban a nemzetközi jogi standardokkal, aminek következtében a törvényhozónak kellene további, főként eljárásjogi szabályokat elfogadnia.

39 Az AB határozat 34. pontja.

40 Az ENSZ Egyezmény ratifikációja a 2010. évi 221. törvénnyel történt. Megjelent: Románia Hivatalos Közlönye, 2010. november 26, 792. sz. Az Egyezmény 12. cikkének rendelkezései, melyek az alkotmánybírósági határozatra utaltak: „(2) A részes államok elismerik, hogy a fogyatékossággal élő személyeket az élet minden területén másokkal azonos alapon megilleti a jog-, illetöleg cselekvőképesség. (3) A részes államok meghozzák a szükséges intézkedéseket, hogy annak érdekében, hogy a fogyatékossággal élő személyek cselekvőképességének gyakorlásához esetlegesen szükséges segitség hozzáférhetővé váljon. (4) A részes államok biztositják, hogy a cselekvőképesség gyakorlására vonatkozó valamennyi intézkedés, a nemzetközi emberijoggal összhangban, megfelelö és hatékony biztositékokat tartalmaz a visszaélések megelőzésére. Az ilyen biztositékok garantálják, hogy a cselekvőképesség gyakorlására vonatkozó intézkedések tiszteletben tartják a személy jogait, akaratát és választásait, összeférhetetlenségtől és indokolatlan befolyástól mentesek, arányosak és a személy körülményeire szabottak, a lehetö legrövidebb idöre vonatkoznak, továbbá hogy a hatáskörrel rendelkezö, független és pártatlan hatóság vagy igazságügyi szerv rendszeresen felülvizsgálja azokat. A biztositékok azzal arányosak, amilyen mértékben az adott intézkedések érintik a személy jogait és érdekeit."

41 Az AB határozat 39. pontja. 
Végül az Alkotmánybíróság arra a következtetésre jutott, hogy a gondnokság alá helyezés jogintézménye a jelenlegi szabályozás szerint, mely azt eredményezi, hogy az érintett személy teljes mértékben elveszíti a jogi cselekvőképességét, nincsen kellő, a személyt védő garanciákkal ellátva. A cselekvőképesség ilyen formában történő elvesztése sérti az emberi méltóságot is, ami alkotmányos alapérték, és hasonlóképpen sérül a személyiség legfőbb értékként tételezett szabad fejlődése. Ez utóbbi vonatkozásában, szoros összefüggésben az emberi méltósággal, sérül ennek mind az aktív oldala, mely a szabad cselekvésre, mind a passzív oldala, mely az egyén magánszféráját érintő személyiségi jogokra vonatkozik. ${ }^{42}$

Az Alkotmánybíróság, a döntés rendelkező része értelmében, az Rptk. 164. cikkének (1) bekezdése alkotmányellenes, mivel ez sérti az alaptörvény emberi méltóságra és a személyiség szabad fejlődésére vonatkozó rendelkezéseit, az ezzel kapcsolatosan kialakult alkotmánybírósági esetgyakorlatot, a jogegyenlőséget, valamint a fogyatékos személyek védelmét elrendelő alkotmányi rendelkezést, melyet a vonatkozó nemzetközi Egyezmény 12. cikke szerint kell értelmezni, azaz „a fogyatékos személyeknek is joguk van a teljes jogképességre".

Kétségtelen, hogy az Alkotmánybíróság mindezen elvi (egyébként kötelező erejü) megállapításai komoly feladatot rónak a Parlamentre, mely viszonylag rövid időn belül el kell hogy fogadja a megfelelő szabályokat, mert jelen pillanatban a 164-es cikk (1) bekezdése semmilyen (eddigi) formában nem alkalmazható.

Összegzésképpen arra a következtetésre jutottunk, hogy miközben megfelelő különbségtételt kell alkalmazni az alkotmányjogilag szabályozott alapvető emberi jogok és a Polgári törvénykönyvben szabályozott személyiségi jogok között, jelentős átfedések, érintkezési pontok is kimutathatók, melyek nagymértékben viszonylagossá teszik az éles határokat a különböző jogágak, esetünkben az alkotmányjog és a polgári jog között. Ez annál is inkább jelentős, mivel a közjog és a magánjog két meghatározó területéről van szó, tehát ez a klasszikusnak mondható római jogi megkülönböztetés (közjog és magánjog) sem tekinthető abszolútnak. Ugyanakkor a jog egészének nagyon is érzékeny differenciáltsága mellett, mely jelenséget új jogágak megjelenése is igazol, a jog egysége is erősödik, köszönhetően olyan jogon túli vagy éppen jog feletti alapértékek alkotmányi szentesítésével, mint amilyen az emberi méltóság, a személyiség szabad fejlődése vagy éppen az igazságosság.

Mindezek pedig igazolják a jog összetett, többrétegủ és különböző természetủ értéktartalmát, kiszélesítve, kiteljesítve ezzel társadalmi funkcióját és rendeltetését.

\section{Irodalomjegyzék}

1. BALoGH Zsolt: Az emberi méltóság: jogi absztrakció vagy alanyi jog, Iustum Aequum Salutare, 2010/4.

2. Constituția României. Comentarii și explicații, szerk. Cristian IonEscu, Corina Adriana Dumitrescu, Editura C.H. Beck, București, 2017.

42 Az AB határozat 44-45. pontjai. 


\section{ERDÉLYI JOGÉLET}

3. Constituția României. Comentariu pe articole, ediția 2, szerk. Ioan Muraru, Elena Simina TĂNĂSEScu, Editura C.H. Beck, București, 2019.

4. Kecskés László: Polgári jog. A személyek joga, Dialóg Campus Kiadó, Budapest-Pécs, 2007.

5. KLICsu László: Az emberi méltóság a német Alkotmánybíróság egyes döntéseiben, Iustum Aequum Salutare, 2010/4.

6. Philippe Malaurie, Laurent Aynès: Les personnes. Les incapacités, Ed. Cujas, Paris, 1999.

7. Noul Cod Civil. Comentariu pe articole, szerk. Flavius-Antoniu BaIAs, Eugen ChELARU, Rodica Constantinovici, Ioan Macovei, Editura C.H. Beck, București, 2014.

8. Sólyom Péter: Alapjogokra hangolva. A Lüth-ítélet jogtörténeti nézőpontból, Fundamentum, 2007/3.

9. Sztranyiczki Szilárd, Kokoly Zsolt: Román polgárijog. Személyek, Forum Iuris Könyvkiadó, Kolozsvár, 2021.

10. Ovidiu Ungureanu, Cornelia Munteanu: Drept civil. Persoanele, în reglementarea noului Cod civil, Editura Hamangiu, București, 2013.

11. VEREss Emőd: A román magánjog fordulópontjai = Román polgári törvénykönyv, Forum Iuris Könyvkiadó, Kolozsvár, 2017.

12. ZAKARIÁs Kinga, BENKE Károly: Demnitatea umană în jurisprudenta instantelor constituționale din Germania, Ungaria și România, Buletinul Curții Constituționale, 2012/2.

13. ZAKARIÁs Kinga: Az emberi méltósághoz való alapjog, Összehasonlitó jogi elemzés a német és magyar alkotmánybírósági gyakorlat tükrében, Pázmány Péter Katolikus Egyetem, Jog- és Államtudományi Kar, Doktori Iskola, Budapest, 2017. 